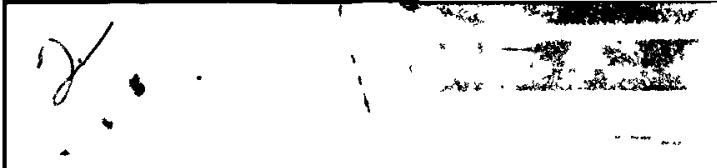

SAVANNAH RIVER LABORATORY

TECHNICAL DIVISION
DP ST $-82-842$

DPST--82-842

DE83 005045

DI STRIBUTION:

G. F. CURTIN, WILM.

F. E. KRUESI

J. E. CONAWAY

J. T. GRANAGHAN, SRP

A. H. PETERS

T. HENDRICK

S. MIRSHAK, SRL

J. R. HILLEY

J. L. CRANDALL

J. M. BOSWELL

J. A. KELLEY

MEMORANDUM
S. D. HARRIS

P. L. ROGGENKAMP

R. W. BENJAMIN

L. A. HEINRICH

J. E. HOISINGTON

D. E. HOSTETLER

I. M. MACAFEE

F. J. MCCROSSON

W. R. MCDONELL -

G. F. O'NEILL

TIS FILES (2)

SEPTEMBER 16,1982

REVISED: OCTOBER 6, 1982

TO: P. L. ROGGENKAMP

FROM: J. E. HOISINGTON

\title{
RADIOISOTOPES FOR HEAT-SOURCE APPLICATIONS
}

\section{INTRODUCTION}

Strontium-90, promethium-147, and plutonium-238 are radionuclides that can be used as heat source materials in high reliability, noninterruptible power supplies. Interest has recently been expressed in their utilization for Department of Defense (DOD) applications. This memorandum summarizes the amounts available and provides unit recovery costs for each of the radioisotopes.

\section{SUMMARY}

Potential DOD requirements for noninterruptable power sources could total $1 \mathrm{MW}$ thermal by FY1990. Of the three isotopes considered, Sr-90 is the only one available in sufficient amounts to meet this requirement. To meet the DOD FY1990 requirements, it would be necessary to undertake $\mathrm{Sr}-90$ recovery operations from spent fuel reprocessing at SRP, Hanford, and the Barnwell Nuclear Fuels Plant (BNFP). Sr-90 recovery from the existing alkaline high level waste (HLW) at Hanford and SRP is not attractive because the isotopic purity of the $\mathrm{Sr}-90$ is below that required for DOD applications. 


\section{DISCLAIMER}

This report was prepared as an account of work sponsored by an agency of the United States Government. Neither the United States Government nor any agency Thereof, nor any of their employees, makes any warranty, express or implied, or assumes any legal liability or responsibility for the accuracy, completeness, or usefulness of any information, apparatus, product, or process disclosed, or represents that its use would not infringe privately owned rights. Reference herein to any specific commercial product, process, or service by trade name, trademark, manufacturer, or otherwise does not necessarily constitute or imply its endorsement, recommendation, or favoring by the United States Government or any agency thereof. The views and opinions of authors expressed herein do not necessarily state or reflect those of the United States Government or any agency thereof. 


\section{DISCLAIMER}

Portions of this document may be illegible in electronic image products. Images are produced from the best available original document. 
Without reprocessing LWR spent fuel, SRP and Hanford could not supply the demand of $1 \mathrm{MW}$ thermal until FY1996. Between FY1983 and FY1996, SRP and Hanford could supply approximately $0.70 \mathrm{MW}$ of Sr-90 and $0.15 \mathrm{MW}$ of Pm-147. SRP could supply an additional 0.15 MW from the production and recovery of Pu-238.

Strontium-90 is the most economical of the three heat source radionuclides considered. The Sr-90 unit recovery cost from SRP fresh acid waste would be $\$ 180 /$ watt. The BNFP SI-90 recovery cost would be $\$ 130 /$ watt to $\$ 235 /$ watt depending on the age and burnup of the LWR spent fuel. Hanford $\mathrm{Sr}_{\mathrm{r}} 90$ recovery costs from Purex fresh acid waste are unavailable, but they are expected to be comparable to the SRP costs. $\mathrm{Pm}-147$ and $\mathrm{Pu}-238$ are considerably more expensive heat source materials. $\mathrm{Pm}-147$ recovery costs at SRP are estimated to be $\$ 450 /$ watt. As with Sr-90, the Hanford Pm-147 recovery costs are expected to be comparable to the SRP costs. Production of high assay ( $83.5 \%) \mathrm{Pu}-238$ at SRP from excess Np-237 would cost about $\$ 1160 /$ watt, while recovery of low assay (27\%) $\mathrm{Pu}-238$ from the waste stream is estimated at $\$ 1850 /$ watt.

\section{DISCUSSION}

\section{Projected Requirements}

Although no firm projections of DOD requirements for heat source radionuclides are available, informal discussions with DOE Headquarters and Hanford personnel studying beneficial applications of waste radionuclides indicate that prospective applications could require a total heat output of $1 \mathrm{MW}$ or more to power a series of thermoelectric generator units with $2 \mathrm{~kW}$ electrical outputs. In addition, many smaller units up to $500 \mathrm{~W}$ (electric) might also be required. Emplacement of the units by FY1990 is indicated.

Strontium-90, promethium-147 and plutonium-238 are potential heat source materials for the high-reliability, non-interruptable DOD power supplies. 1 Strontium-90 ( $148 \mathrm{Ci} /$ watt, half-life 28 years) has been used to power automatic weather, navigation, and communication stations in both terrestrial and marine environments. 1,2 Promethium-147 (2788 Ci/watt, half-life 2.6 years) has been developed for use as a thermal power source in specialized instrumentation systems.1, 3 Plutonium-238 ( $30 \mathrm{Ci} /$ watt, half-life 87.4 years) has been used to power instrumentation systems aboard U.S. space missions. 1

The DOD applications of $\mathrm{Sr}-90$ are assumed to be based on a general purpose thermoelectric generator developed by Teledyne. The Sr-90 heat source in this generator utilizes SrF 2 compacts of 
DPST $-82-842$

September 16, 1982

Rev. $10 / 6 / 82$

about 2-in. in diameter contained in an inner capsule of Hastelloy C-276 and an outer capsule of Hastelloy $\mathrm{C}-4$ or S. 4 The heat load of the capsule is about 1000 watts ( $148 \mathrm{Ci} /$ watt). With a Sr-90 isotopic purity of $55 \%$ the capsule power density is 1 watt/cc. The heat source design requires a minimum Sr-90 purity of $40 \%$ to maintain the thermal power density required for thermoelectric generators.

No heat source design for the $\mathrm{Pm}-147$ applications has been specified, but previous development indicates this radionuclide would be used as $\mathrm{Pm}_{2} \mathrm{O}_{3}$ pellets in heater units or thermoelectric generators similar to the Sr-90 units. 3

The Pu-238 applications are assumed to employ the General Purpose Heat Source (GPHS) design that is routinely produced at SRP. The GPHS consists of $\mathrm{PuO}_{2}$ pellets compacted to $85 \%$ of theoretical density with hot pressing techniques. The pellets are then encapsulated in an iridium alloy for use as heat sources. GPHS capsules produced from $83.5 \% \mathrm{Pu}-238$ will have a power density of 4.0 watts/cc, while capsules from low assay Pu-238 will have a power density of 1.3 watts/cc. Both Pu-238 assays produce a heat source with a power density greater than the proposed Sr-90 design.

\section{Radioisotope Feed Sources}

\section{Strontium-90}

Approximately $0.3 \mathrm{MW}_{\mathrm{t}}$ (45 $\mathrm{MCi}$ ) per year of $\mathrm{Sr}-90$ could be available with recovery operations at SRP, Hanford, and BNFP. This number is based on recovery from fresh acid waste streams. The Sr-90 in the existing HLW inventories at SRP and Hanford is not useful because the isotopic purity of the Sr-90 in the inventories is below the minimum $40 \%$ required for the thermoelectric designs. Table 1 summarizes the annual amounts of Sr-90 available.

SRP can recover about $0.05 \mathrm{MW}_{t} / \mathrm{yr}$ of $\mathrm{Sr}-90$ from fresh acid waste. Four SRP reactors produce approximately $0.07 \mathrm{MW}_{\mathrm{t}}$ (10 $\mathrm{MCi}$ ) per year of $\mathrm{Sr}-90.5,6,7$ The proposed recovery process is $72 \%$ efficient resulting in an annual recovery rate of 0.05 $\mathrm{MW}_{\mathrm{t}} / \mathrm{yr}^{8} \mathrm{8}$

Hanford can recover about $0.018 \mathrm{MW}_{t}(2.3 \mathrm{MCi})$ per year from processing the annual $\mathrm{N}$-reactor discharges. N-reactor produces about $25 \%$ as much $\mathrm{Sr}-90$ as SRP or $0.02 \mathrm{MW}_{\mathrm{t}} / \mathrm{yr}(2.5 \mathrm{MCi} / \mathrm{yr})$. The recovery process at Hanford is $90 \%$ efficient producing $0.018 \mathrm{MW}_{t} /$ yr of $\mathrm{Sr}-90$. 
Hanford does have about $0.08 \mathrm{MW}_{\mathrm{t}}$ of undiluted $\mathrm{Sr}-90$ in $\mathrm{N}$-reactor fuel (2800 MTU) irradiated between 1972 and 1981. This fuel is in cooling basins awaiting the scheduled FY1984 restart of the Purex processing plant.

The amount of Sr-90 that could be recovered from LWR spent fuel if the BNFP plant were to be started up is about $0.25 \mathrm{MW}_{t} / \mathrm{yr}$. The recovery rate is limited by the capacity of BNFP. BNFP could produce $0.3 \mathrm{MW}_{t} / \mathrm{yr}$ of Sr-90 from 5-year old LWR fuel and 0.2 $\mathrm{MW}_{t} / \mathrm{yr}$ from 20-year old fuel when processing $1500 \mathrm{MTU} /$ year with a $72 \%$ efficient Sr-90 recovery process. This number is about half of the annual LWR Sr-90 production of $0.5 \mathrm{MW}_{t}$ /year. 9 The current Sr-90 inventory in LWR spent fuel is estimated at $2.0 \mathrm{MW}_{t}$. This inventory is distributed throughout the country in the cooling basins of power reactors. Since the fuel has not been processed, the only dilution in $\mathrm{Sr}-90$ isotopic purity is that due to radioactive decay.

\section{Promethium-147}

About $0.02 \mathrm{MW}_{t}(60 \mathrm{MCi})$ per year of $\mathrm{Pm}-147$ can be produced for heat source applications with recovery operations at SRP, Hanford, and BNFP (Table 1). The quantities potentially available from SRP and Hanford are $0.015 \mathrm{MW}_{\mathrm{t}} / \mathrm{yr}$ and $0.004 \mathrm{MW}_{\mathrm{t}} / \mathrm{yr}$, respective$1 y .5,6,7$ These values are based on the recovery efficiencies as sumed for Sr-90. The recovery of $\mathrm{Pm}-147$ from LWR spent fuel is only attractive when reprocessing relatively fresh spent fuel. Approximately $0.005 \mathrm{MW}_{t} / \mathrm{yr}(14 \mathrm{MCi} / \mathrm{yr})$ can be recovered at BNFP when processing 5-year old fuel. (Recovery from 20-year old fuel would produce less than $0.1 \mathrm{MCi} / \mathrm{yr}$.)

\section{Plutonium-238}

The annual amounts of $\mathrm{Pu}-238$ that could be produced by SRP are shown in Table 1. Production of high assay $\mathrm{Pu}-238$, containing $83.5 \% \mathrm{Pu}-238$, from excess $\mathrm{NP}-237$ could average $14.5 \mathrm{~kg} /$ year $(0.008$ $\mathrm{MW}_{t} / \mathrm{yr}$ ) of Pu-238 between FY1983 and FY1997. Recovery of low assay $\mathrm{Pu}-238$, containing $27 \% \mathrm{Pu}-238$, from the H-area waste stream would provide an additional $3 \mathrm{~kg}$ of $\mathrm{Pu}-238$ per year $(0.003$ $\mathrm{MW}_{\mathrm{t}} / \mathrm{yr}$ ) during the study period. 10 
Facilities Required

\section{Strontium-90}

Both SRP canyons require modification to provide Sr-90 recovery capability. The Sr-90 would be recovered from the acid waste stream using a lead sulfate carrier precipitation. Each canyon would require at least one centrifuge and several processing tanks to recover a strontium nitrate solution from the waste stream. In F-canyon, space for Sr-90 processing equipment could be made available by removing the $1 \mathrm{~A}$ bank jumbo mixer-settlers (not currently used) and by reallocating the existing canyon tankage. This conflicts with the Mark 15 program, which proposes to replace the jumbo mixer-settlers with a new bank of mixer-settlers to provide additional product decontamination. Space in H-canyon could be made available by removing one or two non-essential tanks and by reallocating the remaining tanks. An alternative would be to remove the H-frames and install the $\mathrm{Sr}-90$ equipment in their place. Removal of the H-frames is not acceptable if Pu-238 production is required along with $\mathrm{Sr}-90$.

All strontium nitrate solutions recovered in H-canyon would be transported to F-canyon for purification and encapsulation in the Multi-Purpose Processing Facility (MPPF). In addition to the Sr-90 recovery equipment, H-canyon would need Sr-nitrate loadout facilities and F-canyon would need Sr-nitrate receiving facilities. Viability of this transfer by truck was not evaluated in detail. If an interarea transfer line is required, unit costs would about double.

The Multi-Purpose Processing Facility (MPPF), located in the F-area "hot" canyon, would be used to encapsulate the Sr-90 recovered at SRP. Almost all the equipment currently installed in the MPPF is expected to require extensive modification or replacement for Sr-90 encapsulation. The existing equipment does not appear to have the required throughput capability required for a Sr-90 encapsulation program. However, a detailed engineering review of the facility capabilities would be required to verify the current facility capacity.

Encapsulation of Sr-90 in the MPPF would most likely conflict with other planned programs. The Mark 42 program and the program for processing the offsite fuel currently in RBOF will require the MPPF facilities beginning in FY 1985 for 2 to 4 years. The program for reprocessing Rocky Flats plutonium, also scheduled during this time frame, would require the MPPF to recover Am-241 from the plutonium. Program prioritization and a detailed facility schedule are required to prevent conflicts among these various programs. 
Hanford currently removes $C s-137$ and Sr-90 from the HLW with the B-plant fractionation process. 11 Contacts with Pacific Northwest Laboratories ( $P N L$ ) personnel indicate the $B-p l a n t$ process could easily be converted to process fresh acid waste from Purex. A new waste header from Purex to B-plant and some minor modifications to the Cs removal columns would be required.

Process equipment for Sr-90 encapsulation at Hanford is located in the Waste Encapsulation and Storage Facility (WESF). This facility is operated in conjunction with the B-Plant for recovery of Sr-90 and Cs-137. The WESF is a shielded, manipulator-operated facility similar in basic configuration to the Savannah River MPPF. Strontium-90 recovered from the HLW is currently encapsulated as $\mathrm{SrF}_{2}$. Production of heat source quality $\mathrm{Sr}_{-90}$ capsules in WESF could be done with minor equipment changes.

Separation and encapsulation of Sr-90 recovered at BNFP from LWR spent fuel would require installation of special facilities. BNFP, as built, has the capability of separating uranium and plutonium from the acid fission product stream. Uranium is converted to $\mathrm{UF}_{6}$, and plutonium is stored as a nitrate solution. 12 The precipitation tanks and centrifugation equipment required to separate the Sr-90 from the other fission products would be located in shielded areas near the existing solvent extraction equipment. Remote cells similar to the SRP MPPF would be required to purify and encapsulate the $\mathrm{Sr}-90$. BNFP would have to construct similar type facilities for converting $\mathrm{Pu}$ nitrate to $\mathrm{PuO}_{2}$ before it could begin reprocessing spent fuel. The cost of the Sr encapsulation facilities could be minimized by combining them with the Pu conversion facility.

\section{Promethium-147}

Most of the facilities required for SRP $\mathrm{Sr}-90$ recovery are suitable for $\mathrm{Pm}-147$ recovery. The precipitation equipment required in the SRP canyons for Sr-90 can be used without modification for concurrent $\mathrm{Sr}-90 / \mathrm{Pm}-147$ recovery. The MPPF as modified for Sr-90 encapsulation can also be used for $\mathrm{Pm}-147$. The basic equipment required is similar for both radionuclides. Some minor modifications may be required to provide the MPPF with the capability of encapsulating two products.

Pm-147 recovery at Hanford and BNFP would also employ the same facilities provided for Sr-90. Minor modifications in the encapsulation facilities would be required to support the additional product output. 


\section{Plutonium-238}

The high assay $\mathrm{Pu}-238$ can be produced in existing SRP facilities without modification. These facilities have enough capacity to accommodate the additional Pu-238 for DOD applications along with the current production commitments. 10

Recovery of low assay Pu-238 would require facility modifications. New ion exchange facilities would have to be installed in H-canyon to remove the Pu from the HM waste stream. Additional shielding in the $\mathrm{HB}-1$ ine would be required for routine processing of low assay $\mathrm{Pu}-238.10$

\section{Costs and Schedules}

\section{Strontium-90}

The total capital cost for removing Sr-90 from fresh SRP waste is estimated at 30 million FY1983 dollars. 8 F and $\mathrm{H}$ canyons would require approximately $\$ 10$ million each for the $S r-90$ recovery modifications. The required modifications to the MPPF facilities are estimated at 10 million dollars. The MPPF costs could be significantly lower if some of the currently installed equipment can be utilized. Incremental operating costs for Sr-90 recovery at SRP are estimated at $\$ 3 \mathrm{million} / \mathrm{yr}$. R\&D costs are estimated to average $\$ 0.7 \mathrm{million} / \mathrm{yr}$ over four years beginning in FY1983.

Initial Sr-90 recovery from fresh SRP waste could begin as soon as FY1986. This schedule would require supplemental funding and acceleration of the R\&D program. The listed quantities of Sr-90 available from SRP and the unit recovery costs are based on a FY1988 startup at SRP. A FY1988 startup assumes a FY1986 project with all design completed in FY1986. Construction of the required facilities would then be completed in FY1987 with startup in FY1988.

Capital and operating costs for recovery of Sr-90 at Hanford are not available. Contacts with PNL personnel indicate that the $S r$ recovery costs from fresh acid Purex waste should be comparable to SRP recovery costs. Recovery of Sr-90 from fresh acid waste would not begin until FY1985. A year delay from the FY1984 Purex startup is assumed to provide a working inventory for B-plant.

The cost of $\mathrm{Sr}$ removal facilites at BNFP is estimated at $\$ 100$ million FY1983 dollars. 13 After escalation to FY1983 dollars, this is 50\% of a capital cost estimate reported by Exxon in 1977 for a cesium and strontium recovery facility. About $50 \%$ of the 
capital would be required for the separations facilities and $50 \%$ for the encapsulation facilities. The annual operating cost is estimated at $\$ 20$ million. As with the capital cost, the operating cost is $50 \%$ of that reported for the Exxon plant, escalated to FY1983 dollars. No R\&D costs are included.

Strontium-90 cannot be recovered at BNFP until the facility begins reprocessing LWR spent fuel. Projected startup in FY1988 would require immediate funding authorization for spent-fuel reprocessing.

\section{Promethium-147}

The total capital cost for recovering $\mathrm{Sr}$ and $\mathrm{Pm}$ from fresh SRP waste is estimated at 35 million 1983 dollars. 8 This is an incremental increase of $\$ 5$ million over the corresponding Sr-90 only recovery costs. It covers additional equipment required in the MPPF to process the two products concurrently. No additional canyon facilities are required for $\mathrm{Pm}-147$ recovery beyond those needed for Sr-90 recovery. The MPPF operating costs for Pm-147 and $\mathrm{Sr}-90$ recovery are estimated to increase by $50 \%$ to $\$ 4.5$ million/yr over those for $S r-90$ alone. No additional operational costs are expected in the canyon for recovery of Pm. $\mathbf{R} \otimes D$ costs are estimated to be $25 \%$ more than for Sr-90 only. Recovery of Pm would begin in FY1988 at the same time as Sr-90 recovery.

The capital and operating costs for recovery of $\mathrm{Pm}-147$ at Hanford are not available. It is expected that the amounts of capital required to provide $\mathrm{Pm}$ encapsulation capability in the WESF would be about equal to that for the MPPF. The WESF operating costs are expected to increase about $50 \%$ as was the case with MPPF. B-plant would probably require no significant modifications for recovery of $\mathrm{Pm}-147$ in addition to $\mathrm{Sr}-90$.

The recovery of $\mathrm{Pm}-147$ in conjunction with $\mathrm{Sr}-90$ at BNFP is estimated to cost 125 million 1983 dollars. The $\$ 25$ million increase over the Sr facilities is principally for additional encapsulation capability. The operating costs should also increase $25 \%$ to about $\$ 25 \mathrm{million} / \mathrm{yr}$. $\mathrm{Pm}-147$ and $\mathrm{Sr}-90$ recovery facilities at BNFP would have the same FY1988 startup date as the Sr-90 only facilities.

\section{Plutonium-238}

No additional capital is required to produce additional high assay Pu-238 for DOD heat source applications. 10 The existing Pu-238 facilities have enough capacity to accommodate the increased production. Incremental operating costs, which include a charge for displaced $\mathrm{Pu}-239$ production, will average 9.5 million 
P. L. Roggenkamp

DPST $-82-842$

September 16, 1982

1983 dollars per year. Production of this additional high assay Pu-238 could begin immediately in FY1983 upon receipt of additional operating funds.

The capital cost for low assay Pu-238 recovery is approximately 4 million FY1983 dollars. 10 New ion-exchange facilities will cost $\$ 2.5$ million, and the HB-line shielding upgrades will cost $\$ 1.5$ million. Annual operating costs are estimated at $\$ 5.0$ million.

The low assay recovery costs are based on a FY1986 project with all design completed in FY1986. Construction would be completed in FY1987 followed by startup in FY1988. The costs are based on batch extraction of the Pu-238 in B-canyon with existing facilities from FY1983 through FY1987. The extracted product would be stored until FY1988 when the HB-1ine facilities are available to convert the product to the oxide. The capital facilities for low assay Pu-238 recovery could be available as early as FY1986 with supplemental funding.

\section{Unit Costs}

The unit costs for heat source radionuclides range from $\$ 81 /$ watt to $\$ 4800 /$ watt. Table 2 shows that $\mathrm{Sr}-90$ is the most economical source, while $\mathrm{Pu}-238$ is the most expensive. These unit costs are calculated from a discounted cash flow analysis. The analysis assumes a 15-year study period from FY1983 through FY1997. A $10 \%$ discount rate is employed which approximates the cost of government debt over the projected time. Details of the discount analysis, along with cash flow tables for the various options, are published in references 8 and 10.

\section{$\underline{\text { Strontium-90 }}$}

The unit recovery costs for Sr-90 range from $\$ 130 /$ watt to $\$ 235 /$ watt. Table 2 shows that BNFP is potentially the most economical source producing $0.3 \mathrm{MW}_{t} / \mathrm{yr}$ at $\$ 130 /$ watt when processing 5-year old LWR fuel. However, BNFP operation is not yet scheduled, and if it is, BNFP will presumably preferentially process older LWR fuel. The BNFP recovery cost increases to $\$ 235 /$ watt if 20 -year fuel is processed. Approximately $0.05 \mathrm{MW}_{t} /$ year of $\mathrm{Sr}-90$ can be recovered from SRP fresh acid waste at a cost of $\$ 183 /$ watt. Hanford Sr-90 recovery costs are expected to be comparable to those shown for SRP acid waste recovery. 


\section{Promethium-147}

Since $\mathrm{Pm}-147$ and $\mathrm{Sr}-90$ are recovered concurrently, the unit recovery costs are calculated on an allocated basis. The cost allocation assigns $50 \%$ of the capital and operating costs to each isotope. This method is probably the most reasonable for determining the Pm-147 recovery cost since most the facilities required for $\mathrm{Pm}$ recovery are also required for $\mathrm{Sr}$ recovery. Cost allocation increases the $\mathrm{Pm}-147$ cost to a more equitable level (relative to the incremental cost) and reduces the Sr-90 cost to reflect the economic advantages of recovering two isotopes.

Table 2 shows that SRP provides the most economical source of $\mathrm{Pm}-147$. SRP can supply $0.013 \mathrm{MW}_{t} / \mathrm{yr}$ at a cost of $\$ 443 /$ watt. Cost allocation reduces the SRP Sr-90 recovery cost from $\$ 183 /$ watt to $\$ 118 /$ watt. The BNFP Pm-147 cost is $\$ 4798 /$ watt. Recovery of both $\mathrm{Pm}$ and $\mathrm{Sr}$ at $\mathrm{BNFP}$ reduces the $\mathrm{Sr}-90$ cost to $\$ 81 /$ watt. The BNFP recovery cost is strongly influenced by the short 2.6 year half-life of Pm-147. With 5-year old LWR spent fuel the Pm-147 content is only $25 \%$ (two half-lives) of the original discharged value. The facility capital and operating cost requirements are dependent on the quantity of fuel processed rather than the amount of $\mathrm{Pm}-147$ recovered. The older age of the LWR fuel versus the age of SRP fuel at the time of processing results in the higher $\mathrm{Pm}-147$ unit recovery costs at $B N F P$.

\section{Plutonium-238}

Plutonium-238 is the most expensive heat source radionuclide studied. The Pu-238 costs are a factor of ten higher than the Sr-90 recovery costs. The unit costs shown in Table 2 are based on incremental capital and operating costs. The high assay $\mathrm{Pu}-238$ can be produced and encapsulated at a cost of $\$ 1162 /$ watt. The low assay Pu-238 can be recovered at $\$ 1849 /$ watt. The low assay Pu-238 is more expensive than the high assay material because of the capital expenditures required for reactivating the low assay $\mathrm{Pu}-238$ capability in H-area.

\section{Heat Source Requirements versus Availability}

Strontium-90 is the only isotope of the three considered that is available in sufficient quantities to meet the potential DOD requirement of the $I \mathrm{MW}$ themal by FY1990. To meet this requirement, it would be necessary to reprocess spent LWR fuel. SRP fresh acid wastes can supply about $0.15 \mathrm{MW}_{t}$ between FY1988 and FY1990. Hanford can supply an additional $0.24 \mathrm{MW}_{t}$ by FY1990 from the future processing of $\mathrm{N}$-reactor fuels. BNFP has the 
capability of rerovering up to $0.90 \mathrm{MW}_{t}$ of $\mathrm{Sr}-90$ by FY1990 if 5-year old LWR spent fuel is reprocessed.

With the three isotopes discussed, SRP and Hanford could meet the heat source demand of $1 \mathrm{MW}_{t}$ thermal by FY1996. If all three isotopes were recovered between FY1983 and FY1996, SRP could supply $0.44 \mathrm{MW}_{\mathrm{t}}$ of $\mathrm{Sr}-90,0.11 \mathrm{MW}_{\mathrm{t}}$ of $\mathrm{Pm}-147$, and $0.15 \mathrm{MW}_{\mathrm{t}}$ of $\mathrm{Pu}-238$. Hanford could recover $0.28 \mathrm{MW}_{t}$ of $\mathrm{Sr}-90$ and 0.05 $\mathrm{MW}_{\mathrm{t}}$ of $\mathrm{Pm}-147$ during the period.

$\mathrm{JEH}: \mathrm{pph}$ 


\section{References}

1. Carpenter, R. T., "Status of U.S. Radioisotopic Space Power Systems", Isotopes and Radiation Technology, 9(No. 3), 1972.

2. Secken, S. J. and W. A. Bair. "Terrestrial Isotope Power Systems in Perspective", Materials for Radio-Isotope Heat Sources, Eds. D. E. Thomas, W. O. Harms, and R. T. Huntoon, Nuclear Metallurgy, Vol. 14, 1968.

3. Drumheller, K. "Properties and Fabrication of Promethium Fuel Forms", Materials for Radio-Isotope Heat Sources (Nuclear Metallurgy, Voil. 14).

4. Fullam, H. T. Design and Qualification Testing of a Strontium-90 Fluoride Heat Source, Pacific Northwest Laboratory, PNL-3923, Dec. 1981.

5. Waste Management Programs, Report for December 1981, DPSP-81-21-12, Savannah River Plant, December, 1981.

6. Sheldon, E. B., Sr-90 and Pm-147 in Savannah River Plant Waste, DPSP-65-1273, April 19, 1965.

7. Waste Management Programs, Report for December 1980, DPSP-80-21-12, Savannah River Plant, December 1980.

8. Hoisington, J. E. and McDonell, W. R., "Strontium-90 and Promethium-147 Recovery", DPST-82-813, August 30, 1982.

9. Spent Fuel and Radioactive Waste Inventories and Projections as of December 31,1980 , DOE/NE-0017, September, 1981.

10. O'Nei11, G. F., "Additional Pu-238 Productioq", DPST-82-839, to be issued.

11. Technical Aspects of Long-Term Management Alternatives for High-Level Defense Waste at the Hanford Site, RHO-LD-141, October 1980.

12. Evaluation of Utilization of Barnwell Nuclear Fuel Plant in Support of the U.S. Breeder Reactor Reprocessing Program, ORNL/TM-7719, March, 1981.

13. Study of the Separation and Recovery of Selected Radioisotopes from Commercial Nuclear Spent Fuel Wastes, XN-FR-ER-2, Rev. 1, January, 1978. 
Table 1. Radioisotope Feed Sources

\begin{tabular}{|c|c|c|c|c|c|c|}
\hline & \multicolumn{6}{|c|}{ Amounts Available } \\
\hline & \multicolumn{2}{|c|}{ SRP } & \multicolumn{2}{|c|}{ Hanford } & \multicolumn{2}{|c|}{ LWR Spent Fuel } \\
\hline & $\left(M W_{+} / y r\right)$ & $(\mathrm{MCi} / \mathrm{yr})$ & $\left(M W_{t} / y I\right)$ & $(\mathrm{MCi} / \mathrm{yr})$ & $\left(\mathrm{MW}_{\mathrm{t}} / \mathrm{Yr}\right)$ & $(\mathrm{MCi} / \mathrm{yr})$ \\
\hline $5 r-90$ & 0.07 & $10^{a}$ & $0.02^{c}$ & $2.5^{c}$ & 0.5 & 71.0 \\
\hline$P m-147$ & 0.02 & $50^{a}$ & $<0.01$ & 12 & 0.05 & 135.0 \\
\hline $\begin{array}{l}\text { Pu-238 } \\
\text { - High Assay } \\
\text { - Low Assay }\end{array}$ & $\begin{array}{l}0.008 \\
0.003\end{array}$ & $\begin{array}{cc}14.5 & \mathrm{~kg} / \mathrm{y} \\
5 & \mathrm{~kg} / \mathrm{y}\end{array}$ & & & & \\
\hline $\begin{array}{l}\text { a. Four SRP re } \\
\text { b. Average prod } \\
\text { c. in addition } \\
\text { of N-reacto }\end{array}$ & $\begin{array}{l}\text { tors ope: } \\
\text { ction ov } \\
0.08 \mathrm{MW} \\
\text { fue } 1 \text { irr }\end{array}$ & $\begin{array}{l}\text { ting. } 5,6 \\
\text { the } 15- \\
12 \text { MCi) } \\
\text { iated be }\end{array}$ & $\begin{array}{l}\text { s period } \\
\text { Sr-90 is } \\
\text { en } 1972\end{array}$ & $\begin{array}{l}\text { from FY198 } \\
\text { available } \\
\text { nd } 1981 \text {. }\end{array}$ & $\begin{array}{l}\text { to FY1997 } \\
2800 \mathrm{MT}\end{array}$ & 10 \\
\hline
\end{tabular}


Table 2. Unit Recovery Costs

\begin{tabular}{l} 
Annua I \\
Amount \\
(Mw+ $/ \mathrm{yr}$ ) \\
\hline
\end{tabular}

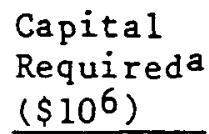

Annua 1 Operatinga Costs $\left(\$ 10^{6} / \mathrm{yr}\right)$
Unit Costa, b (\$/watt)

Strontium-90

SRP Acid Wastec

Hanford Acid Wasted

BNFP

- 5-yr old fuelc

- 20-yr old fuelc
0.05

0.02

0.3

0.2

Promethium-147 (Strontium-90)

SRP Acid Wastec

0.013

$39 e$

100

100

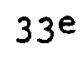

3

183

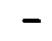

130

235

20

20

4.5

$443^{\mathrm{f}}$

Hanford Acid Wasted

$0.004(0.02)$

BNFP Reprocessing

$0.007(0.3)$

25

5-yr Old Fue ${ }^{c}$

$(118)^{f}$

$-$

$-$

25

$4798^{f}$

$(81)^{f}$

Plutonium-238

High Assay (83.5\%)

Low Assay $(27 \%)$
0.008

0.003 $\overline{4}$
1162

1849

a. Values are FY1983 dollars.

b. Unit costs based on discounted cash flow analysis with $10 \%$ discount rate.

c. The amount recovered is $72 \%$ of the $\mathrm{Sr}$ and/or Pm present in the waste.

d. The amount recovered is $90 \%$ of the $\mathrm{Sr}$ and/or Pm present in the waste.

e. Includes $R \& D$ costs.

f. Unit cost based on $50 \%$ of the capital and operating costs allocated to each isotope. 
E. I. DU PONT de NemOURS \& COMPANy

ATOMIC ENERGY DIVISION

SAVANNAH RIVER LABORATORY

AIKEN, SOUTH CAROLINA 29801

(TWX 810.771.2670 TEL 803.725-6211 WU AUGUSTA GA)

September 16, 1982

Mr. F. H. Allhoff

Savannah River Operations office

U. S. Department of Energy

P. O. Box A

Aiken, South Carolina 29808

Dear Mr. Allhoff:

\section{RADIOISOTOPES FOR HEAT SOURCE APPLICATIONS}

The attached memorandum, "Radioisotopes for Heat Source Applications", DPST-82-842, provides availability and cost information for the possible recovery of strontium-90, promethium-147, and plutonium-238 from nuclear fuel reprocessing operations at SRP, Hanford, and Barnwel1. Of the three isotopes, strontium-90 is available in the largest quantities and is the least expensive to recover. Promethium-147 and plutonium-238 are available only in limited amounts at costs that are 3 to 10 times higher than strontium-90. Recovery of these radioisotopes from the existing high level wastes at SRP and Hanford is not attractive because of unacceptably low isotopic purities and high costs.

Yours very truly,

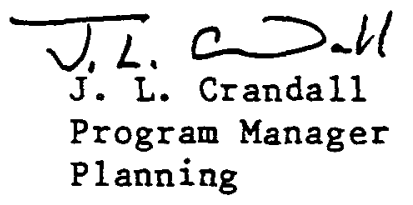

$\mathrm{JEH}: \mathrm{pph}$

Att. 